\section{Kidney \\ Blood Pressure Research}

\title{
Effect of Ascorbic Acid on Mineral and Bone Disorders in Hemodialysis Patients: a Systematic Review and Meta-Analysis
}

\author{
Guibao Ke Junlin Huang $^{\mathrm{b}} \quad$ Yue Zhu $^{\mathrm{b}}$ Jia Yang ${ }^{\mathrm{a}}$ Yamei Zhang ${ }^{\mathrm{c}} \quad$ Lvlin Chen $^{\mathrm{a}}$ \\ Juan Hue Shaoqiang Tao ${ }^{d}$ Yao Hu$^{a}$ Dehua Yang ${ }^{c}$ Shuangxin Liue \\ aDepartment of Internal Medicine, Affiliated Hospital/Clinical Medical College of Chengdu University, \\ Chengdu, ' ${ }^{N}$ anfang Hospital, Southern Medical University First School of Clinical Medicine, \\ Guangzhou, 'Department of Central Laboratory, Affiliated Hospital/Clinical Medical College of Chengdu \\ University, Chengdu, ${ }^{d}$ Chengdu sports institute, Chengdu, eDepartment of Nephrology, Guangdong \\ General Hospital, Guangdong Academy of Medical Sciences, Guangzhou, China
}

\section{Key Words}

Hemodialysis $•$ Chronic kidney disease-mineral bone disorders $•$ Ascorbic acid $\bullet$ Phosphate $•$ Calcium • Parathyroid hormone

\begin{abstract}
Background/Aims: Hemodialysis (HD) patients often have inadequate nutrition, especially with respect to ascorbic acid (AA). It is reported that every HD session may cause a $50 \%-$ $75 \%$ decrease in plasma AA levels. Some studies have shown that supplementation of AA can change the outcome of chronic kidney disease-mineral bone disorders (CKD-MBD), but the effect of $A A$ on $H D$ patients with CKD-MBD remains controversial. Consequently, we decided to perform a meta-analysis to evaluate the efficacy of AA supplementation in CKDMBD patients requiring dialysis. Methods: A search was conducted using Pubmed, EMBASE, Cochrane Central Register of Controlled Trials, Chinese National Knowledge Infrastructure (CNKI), Wanfang database and VIP information database up to April 2018 for all English and Chinese language publications. The main indicators of our study were changes in serum phosphate $(\mathrm{P})$, calcium $(\mathrm{Ca})$ and parathyroid hormone (PTH) levels after AA treatment. The efficacy of AA was evaluated by weighted mean difference (WMD) and confidence intervals (CI). Cardiovascular events, mortality and adverse events reported during the experiment were also noted. Results: In total, 371 patients in six studies were involved in this meta-analysis. Compared to placebo, AA treatment had no positive effect on serum $\mathrm{P}$ (353 patients; WMD = $-0.05 ; 95 \% \mathrm{CI},-0.3$ to $0.2 ; I^{2}=28 \%$ ) or PTH levels ( 275 patients; WMD $=-17.04 ; 95 \% \mathrm{CI},-63.79$ to $\left.29.72 ; I^{2}=75 \%\right)$. The pooled mean difference of the change of Ca levels from baseline was higher in the AA therapy group versus placebo (353 patients; WMD $=0.15 ; 95 \% \mathrm{CI}, 0.01$ to 0.3 ; $\left.R^{2}=0 \%\right)$. No side effects were observed. Conclusion: Our systematic review and meta-analysis

G. Ke, J. Huang and Y. Zhu contributed equally to this work.




\section{Kidney Blood Pressure Research}

Kidney Blood Press Res 2018;43:1459-1471

\begin{tabular}{l|l}
\hline DOI: 10.1159/000493661 & C 2018 The Author(s). Published by S. Karger AG, Base
\end{tabular}

Published online: 21 September, 2018 www.karger.com/kbr

does not support prescription of AA to HD patients with CKD-MBD. AA had no positive effect on CKD-MBD patients as it couldn't influence the serum P or PTH levels but did raise serum Ca levels in the short-term.

(C) 2018 The Author(s)

Published by S. Karger AG, Basel

\section{Introduction}

Over recent decades, chronic kidney disease (CKD) has become a heated public health problem globally as it affects almost $10 \%-15 \%$ of adults worldwide [1]. In 2010, about 1.9 million CKD patients received dialysis because it is an effective treatment for renal failure, greatly improving quality of life [2]. Unexpectedly, the mortality of CKD patients receiving dialysis is 6.1-7.8 times higher compared with the general population [2,3], with those CKD patients who had higher levels of serum calcium (Ca), phosphate (P), and parathyroid hormone (PTH) being particularly at increased risk of death [4-8].

CKD often manifests as $\mathrm{Ca}$ and $\mathrm{P}$ metabolism disorder and hyperparathyroidism, promoting the development of chronic kidney disease-mineral bone disorders (CKD-MBD) including cardiovascular disease (CVD) and renal osteodystrophy [9-12]. CVD is the main cause of death among hemodialysis (HD) patients [13]. Moreover, most older HD patients have secondary hyperparathyroidism (SHPT), which is also one of the adverse complications of CKD, and is characterized by high serum PTH with parathyroid gland hyperplasia, ultimately causing mineral metabolism disorders [14]. Meanwhile, calciphylaxis is mainly observed among CKD patients receiving dialysis [15], and both uremic and non-uremic calciphylaxis are relevant to the significant morbidity and mortality [16].

Consequently, effective control of the levels of serum Ca, P and PTH in CKD patients with HD is important [17]. The Guidelines provided by Kidney Disease: Improving Global Outcomes (KDIGO) suggests that treatments for CKD-MBD, for patients with CKD G3a-G5D, should take into consideration the serial assessments of serum $\mathrm{P}, \mathrm{Ca}$, and $\mathrm{PTH}$ concentrations together (not graded) [18]. Nevertheless, treatment of CKD-MBD remains challenging, as clinicians are supposed to consider multiple biochemical markers while the effects of varied therapies on these markers are complicated and one drug intended to improve one parameter is likely to have unexpected effects on other parameters $[19,20]$.

Long-term HD leads to ascorbic acid (AA) deficiency in CKD patients. It is reported that every HD session may cause a 50\%-75\% decrease in plasma AA levels [21]. Some studies have reported that AA affects activity of the PTH receptor [22] and calcium-sensing receptor (CaSR) of the parathyroid gland [23], and increases the sensitivity of osteoblasts and other PTH target organ systems to PTH. Furthermore, AA plays a key role in the metabolism of vitamin $D$ and the binding process between vitamin D and its target organs [24], which can affect PTH by regulating calcium ion concentration. Due to its anti-inflammatory functions, AA can reduce the expression of inflammatory factors and further affect blood P levels [25]. Consequently, in recent years, some scholars have begun to pay attention to the study of AA effects on CKD-MBD of dialysis patients. Richter et al. proposed that serum AA levels showed an inverse correlation with PTH levels among patients with AA deficiency [26]. However, no consensus has yet been reached on the effect of AA in CKD-MBD patients receiving HD. Xie et al. concluded that Vitamin $C$ dialysate could certainly delay and reduce the occurrence of SHPT by affecting bone circulation to regulate serum ALP concentration [27]. Baradari et al. also implied that intravenous (IV) injection of AA effectively reduced the serum P levels in HD patients, which seemed to alleviate CKD-MBD[28]. However, Deira et al. drew a different conclusion from a prospective and randomized trial over 6 months, finding that with IV AA, serum PTH levels saw a reduction within 3 months but bounced back beyond 3 months [29]. Biniaz et al. also demonstrated that the effect of AA on improving SPTH could not be confirmed during their trial among $82 \mathrm{HD}$ patients, indicating that AA may have no benefit to HD patients with CKD-MBD[30]. In a study by Richter, the therapeutic effect of prescribing AA to treat SHPT could still not be confirmed [26]. 


\section{Kidney Blood Pressure Research}

Ke et al.: Ascorbic Acid on Mineral and Bone Disorders in Hemodialysis Patients

As the effect of ascorbic acid on HD patients with CKD-MBD remains controversial, we decided to perform a meta-analysis to evaluate the effect of AA supplementation in the treatment of CKD-MBD patients requiring dialysis.

\section{Materials and Methods}

\section{Study Design}

The present systematic review and meta-analysis was conducted according to a prespecified registered protocol [31] and the Preferred Reporting Items for Systemic Reviews and Meta-analyses (PRISMA) guidelines.

\section{Data Sources and Search Strategy}

A search was conducted using Pubmed, EMBASE, Cochrane Central Register of Controlled Trials, Chinese National Knowledge Infrastructure (CNKI), Wanfang database and VIP information database up to April 2018 for all English and Chinese language publications. The following terms were used to search the literature: ("Ascorbic Acid" OR "AA" OR "Vitamin C") AND ("Dialysis" OR "Hemodialysis" OR "Hemodialyses" OR "HD" OR "Renal Replacement Therapy") AND ("Parathyroid hormone" OR "Chronic kidney diseasemineral bone disorders" OR "Hyperparathyroidism" OR "PTH" OR "CKD-MBD" OR "SHPT"). The reference list of each publication was also scanned in order to identify additional literature about this topic.

\section{Selection Criteria}

Inclusion Criteria were: (i) patients: adult ( $\geq 18 \mathrm{y}$ ) long-term HD patients; (ii) study design: randomized controlled trial; (iii) outcomes: the studies involved should report at least one outcome of interest; (iv) intervention: the intervention group received AA treatment, while the comparison group received placebo therapy or standard care only.

Exclusion Criteria: Duplicate publications, abstracts, reviews, case reports, comments or editorials, studies without a control group or those not reporting AA treatment with relevant scales as the outcome measures, studies with statistical mistakes, or studies with incomplete data and cell or animal experiments. In the case of multiple publications from the same population, we included the most recent publication.

\section{Data extraction}

Data were extracted independently by two investigators and exported to an Excel database. The following items recorded for each study were extracted: first author, year of publication, study design, mean and $\mathrm{SD}$ of $\mathrm{AA}$, mean and $\mathrm{SD}$ of $\mathrm{Ca}$, mean and $\mathrm{SD}$ of $\mathrm{P}$, dosage of $\mathrm{AA}$, time point of measurement, treatment duration, and method of administering AA. The $\mathrm{P}$ and Ca concentration data were all expressed in $\mathrm{mg} / \mathrm{dL}$ (if the $\mathrm{P}$ or Ca data were presented as $\mathrm{mmol} / \mathrm{L}$, they were converted to $\mathrm{mg} / \mathrm{dL}$ by multiplying by 3.097 or 4.008 respectively), and the PTH data were expressed as $\mathrm{pg} / \mathrm{mL}$ (if the data were presented as $\mathrm{ng} / \mathrm{L}$, they were converted to $\mathrm{pg} / \mathrm{mL}$ ).

\section{Quality assessment}

For the randomized controlled trials, we used the Cochrane collaboration risk of bias (ROB) tool to examine study validity. The overall risk of bias of a study was considered "low" if more than four items were rated as "low risk" by the Cochrane collaboration ROB tool. The overall risk of bias of a study was considered "moderate" if two or three items were rated as "low risk" by the Cochrane collaboration ROB tool. The overall risk of bias of a study was considered "high" if fewer than two items were rated as "low risk" or if more than one item was rated as "high risk" by the Cochrane collaboration ROB tool.

\section{Outcome Measures}

In 2017, control of the P, Ca and PTH levels was considered equally important in the new KDIGO CKDMBD guide [18]. Therefore, the main indicators used in our study were the changes of serum P, Ca and PTH levels after AA treatment. Cardiovascular events, mortality and adverse events reported in the publications were also recorded. 


\section{Kidney Blood Pressure Research}

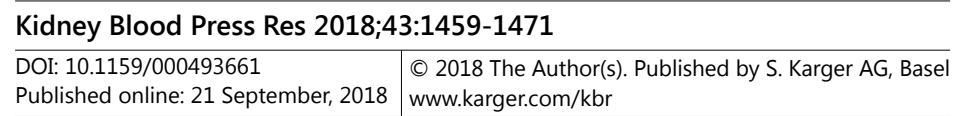

\section{Statistical analysis}

In our study, P, Ca and PTH concentrations were considered as continuous data, and the combined effect sizes utilized WMD. We estimated the amount by which the AA changed the outcome on average in comparison with the placebo. We used a fixed effects or random effects model because it takes into account the heterogeneity across studies and the $I^{2}$ statistic was used to assess heterogeneity. Depending on whether $I^{2}$ was $\leq 50 \%$ or $>50 \%$ to $<75 \%$ or $\geq 75 \%$, heterogeneity was considered low, moderate or high respectively. Pre-stratified subgroup analysis was performed to investigate possible sources of heterogeneity, including the time of measurement and the methods of administration. The presence of publication bias was also evaluated using Egger's tests. All analyses were performed using Stata 12.0 and RevMan 5.3. We considered statistical significance as $P<0.05$.

\section{Results}

\section{Search Results}

The search strategy identified 91 citations: Pubmed: $n=29$, Embase: $n=7$, Cochrane Central Register: $n=5$, CNKI: $n=5$, Wanfang: $n=38$, and VIP information: $n=6$. Twelve duplicate articles were excluded and 79 articles remained for screening. After examining the title and abstract in more detail, a further 60 were excluded, and after reading the full text, 13 articles were excluded because of lack of necessary data. Eventually, six studies were included in this meta-analysis [27-30] [32,33]. The selection process used to identify the studies is shown in Fig. 1.

\section{Study characteristics}

The main characteristics of the six studies included are shown in Table 1. All studies were RCTs and involved a total of 371 participants. Patients of six studies had a long-term HD history, and the intervention groups received AA treatment while the control groups received placebo therapy or standard care only. Based on the quality assessment of Cochrane, four studies were at low risk of bias while the other two were at moderate risk, as shown in Table 2.

Association of $A A$ therapy with P levels

Five studies evaluated the association between AA therapy and serum concentration of $P$ (random effects model: WMD = $-0.05 ; 95 \%$ CI, -0.3 to $0.2 ; P=0.69$; Fig. 2). However, heterogeneity was detected between studies $\left(I^{2}=28 \%\right.$; Fig. $2)$. Moreover, the results of subgroup analyses also showed that none of the subgroups revealed significant efficacy of AA on $P$ levels with differences in the time of measurement (Fig. 2a, Table 3) or the method of administration (Fig. 2b, Table 3).

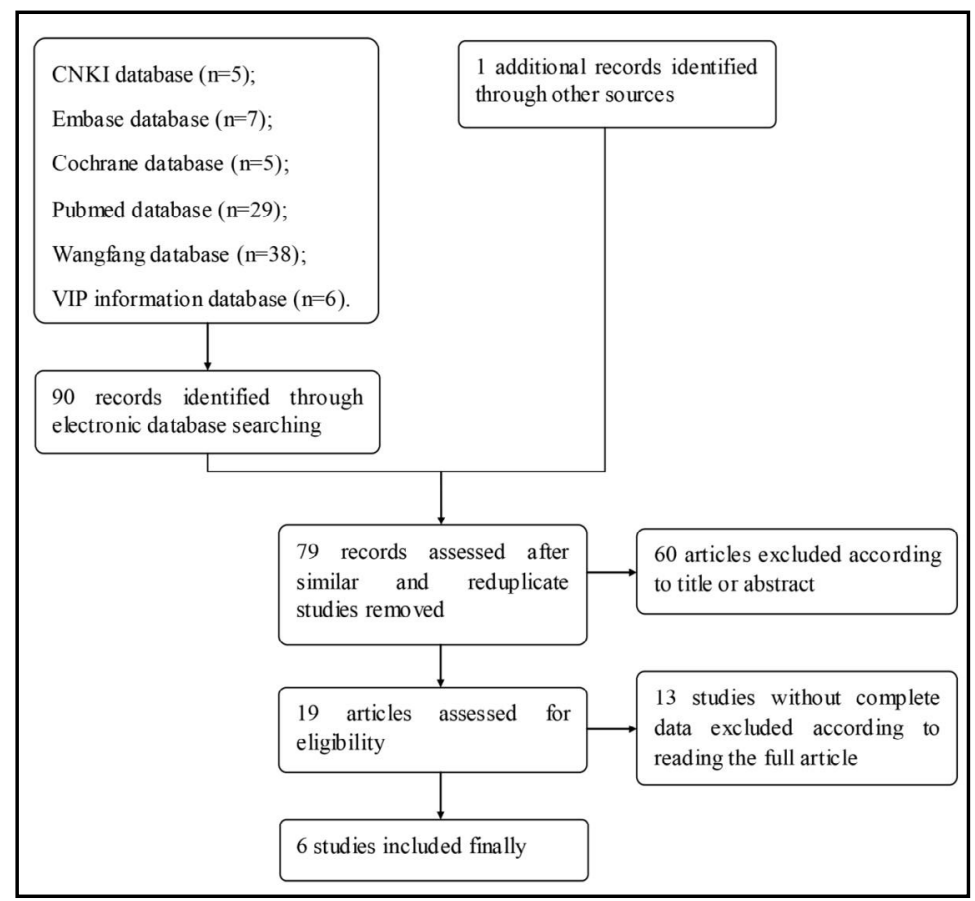

Fig. 1. Flow diagram illustrating the selection of studies for this metaanalysis. 


\section{Kidney Blood Pressure Research}

Table 1. Characteristics of included studies. Data shown as mean [SD]. Abbreviations: AA: ascorbic acid, Con: Control, PTH: parathyroid hormone (pg/mL), Ca: calcium (mg/dL), P: phosphate (mg/dL), DC: dialysis concentration (mg/L), RCT: randomized controlled trial, CKD: chronic kidney disease, ESRD: end-stage renal disease

\begin{tabular}{|c|c|c|c|c|c|c|c|c|c|c|c|}
\hline Study & Region & $\begin{array}{l}\text { Type } \\
\text { of } \\
\text { study }\end{array}$ & Intervention & Control & $\begin{array}{l}\text { Articles were } \\
\text { written in } \\
\text { English or } \\
\text { Chinese } \\
\end{array}$ & $\begin{array}{l}\text { Measurement } \\
\text { Time }\end{array}$ & $\begin{array}{l}\text { Male sex } \\
\text { (AA, Con) }\end{array}$ & Age (years) & $\begin{array}{l}\text { CKD } \\
\text { stage }\end{array}$ & $\begin{array}{c}\text { No. of } \\
\text { Participants } \\
\text { (AA, Con) }\end{array}$ & Baseline laboratory data (AA, Con) \\
\hline $\begin{array}{l}\text { Attallah } \\
\text { et al } \\
(2006)\end{array}$ & $\begin{array}{c}\text { North } \\
\text { America }\end{array}$ & RCT & $\begin{array}{l}300 \mathrm{mg} \text { of intravenous vitamin C } \\
\text { administered at the end of each } \\
\text { hemodialysis session (total of } \\
900 \mathrm{mg} / \mathrm{wk} \text { ) for } 6 \text { months }\end{array}$ & Placebo & English & 6 months & $45 \%, 48 \%$ & $\begin{array}{l}\text { AA } 51[4.7] \\
\text { Con } 49[5.9]\end{array}$ & ESRD & 20,21 & $\begin{array}{l}\text { PTH: } 308[67], 311[76.8] ; \\
\quad \text { Ca: } 9.4[0.7], 9.5[0.5] \text {; } \\
\quad \text { P: } 5.1[0.4], 5[0.6] .\end{array}$ \\
\hline $\begin{array}{l}\text { Baradari } \\
\text { et al } \\
(2012)\end{array}$ & Iran & RCT & $\begin{array}{l}\text { vitamin C vial }(500 \mathrm{mg} / 5 \mathrm{cc}) \\
\text { intravenously three times a week } \\
\text { for } 8 \text { weeks at the end of each } \\
\text { hemodialysis session }\end{array}$ & $\begin{array}{l}\text { Placebo } \\
\text { (saline) }\end{array}$ & English & 8 weeks & $59 \%, 48 \%$ & $\begin{array}{l}\text { AA 60 }[15] \\
\text { Con } 61[13]\end{array}$ & ESRD & 29,29 & $\begin{array}{c}\text { PTH: } 201.6[115.6], 198.5[120.3] ; \\
\text { Ca:8.24[0.75], 8.34[0.9]; } \\
\text { P: } 6.11[2.1], 6.02[2.37] .\end{array}$ \\
\hline $\begin{array}{l}\text { Biniaz } \\
\text { et al } \\
(2013)\end{array}$ & Iran & RCT & $\begin{array}{l}250 \mathrm{mg} \text { vitamin C was injected } \\
\text { three times a week for } 8 \text { weeks at } \\
\text { the end of each hemodialysis } \\
\text { session }\end{array}$ & $\begin{array}{l}\text { Placebo } \\
\text { (saline) }\end{array}$ & English & 8 weeks & $54 \%, 67 \%$ & $\begin{array}{l}\text { AA } 60[12] \\
\text { Con } 61[11]\end{array}$ & ESRD & 37,39 & $\begin{array}{l}\text { PTH: } 699.8[318.85], 596.03[410.3] \text {; } \\
\text { Ca: 8.43(0.49), 8.37(0.71); } \\
\text { P: } 6.008(1.76), 5.787(1.66) .\end{array}$ \\
\hline $\begin{array}{l}\text { Deira } \\
\text { et al } \\
(2003)\end{array}$ & Spain & RCT & $\begin{array}{l}200 \mathrm{mg} \text { of intravenous AA post- } \\
\text { dialysis } 3 \text { times/week for } 6 \\
\text { months }\end{array}$ & Placebo & English & 6 months & $78 \%, 78 \%$ & $\begin{array}{l}\text { AA } 60[22] \\
\text { Con } 60[15]\end{array}$ & ESRD & 9,9 & PTH: 357 [321], 117 [86]. \\
\hline $\begin{array}{l}\text { Xie } \\
\text { et al } \\
(2010)\end{array}$ & China & RCT & $\begin{array}{l}57 \mathrm{mg} / \mathrm{L} \text { vitamin } \mathrm{C} \text { in dialysate } \\
\text { with } 500 \mathrm{~mL} / \mathrm{min} \text { flow three } \\
\text { times a week for } 3 \text { months }\end{array}$ & Placebo & Chinese & 3 months & $60 \%, 53 \%$ & $\begin{array}{l}\text { AA } 63[10] \\
\text { Con } 60[11]\end{array}$ & ESRD & 42,40 & $\begin{array}{l}\text { PTH: } 227.65[11.32], 231.42[13.2] ; \\
\text { Ca: } 8.62[0.8], 8.66[0.56] ; \\
\text { P: } 5.88[1.78], 5.67[1.77] .\end{array}$ \\
\hline $\begin{array}{l}\mathrm{Li} \\
\text { et al } \\
(2011)\end{array}$ & China & RCT & $\begin{array}{l}57 \mathrm{mg} / \mathrm{L} \text { vitamin } C \text { in dialysate } \\
\text { with } 500 \mathrm{~mL} / \mathrm{min} \text { flow three } \\
\text { times a week for } 3 \text { months }\end{array}$ & Placebo & Chinese & 3 months & $60 \%, 61 \%$ & $\begin{array}{l}\text { AA48 [13] } \\
\text { Con } 47[12]\end{array}$ & ESRD & 47,49 & $\begin{array}{l}\text { Ca: } 8.66[0.68], 8.62[0.48] ; \\
\text { P: } 7.28[0.96], 7.19[0.68]\end{array}$ \\
\hline
\end{tabular}

Table 2. Risk-of-Bias Assessment

\begin{tabular}{|c|c|c|c|c|c|c|}
\hline Study & $\begin{array}{c}\text { Adequate random } \\
\text { sequence generation }\end{array}$ & Allocation concealment & $\begin{array}{l}\text { Blinding of participants } \\
\text { and personnel }\end{array}$ & $\begin{array}{l}\text { Adequate assessment of } \\
\text { each outcome }\end{array}$ & $\begin{array}{l}\text { Selective outcome } \\
\text { reporting avoided }\end{array}$ & $\begin{array}{c}\text { Free of } \\
\text { other bias }\end{array}$ \\
\hline Attallah et al, 2006 & Yes & Yes & No & Yes & Yes & Yes \\
\hline Baradari et al, 2012 & Yes & Yes & Yes & Yes & Yes & Yes \\
\hline Biniaz et al., 2013 & Yes & Yes & Yes & Yes & Yes & Yes \\
\hline Xie et al., 2010 & Unclear & Unclear & Unclear & Yes & Yes & Yes \\
\hline Deira et al., 2003 & Yes & Yes & Unclear & Yes & Yes & Yes \\
\hline Li et al., 2011 & Unclear & Unclear & Unclear & Yes & Yes & Yes \\
\hline
\end{tabular}

\section{Association of AA therapy with Ca levels}

Five studies evaluated the association between AA therapy and serum concentration of Ca (fixed effects model: WMD $=0.15 ; 95 \% \mathrm{CI}, 0.01$ to $0.3 ; P=0.03$; Fig. 3 ). The pooled mean difference of the change in Ca levels from baseline was significantly higher in the AA therapy group versus placebo. No heterogeneity was detected between studies $\left(I^{2}=0 \%\right.$; Fig. 3). In addition, prespecified subgroup analysis was carried out according to the time of measurement and the method of administration. Over 8 weeks, AA therapy significantly elevated the levels of serum Ca (fixed effects model: WMD $=0.23 ; 95 \% \mathrm{CI}, 0.03$ to $0.42 ; P$ $=0.02 ; I^{2}=0 \%$; Fig. 3a), but the effects disappeared over 3-6 months (fixed effects model: $\mathrm{WMD}=0.07 ; 95 \% \mathrm{CI},-0.14$ to $0.28 ; P=0.49 ; I^{2}=0 \%$; Fig. 3a, Table 3). Moreover, the results of subgroup analysis indicated that different AA administration methods had no effect on serum Ca levels (Fig. 3b, Table 3).

\section{Association of AA therapy with PTH levels}

Five studies evaluated the association between AA therapy and serum concentration of PTH (random effects model: WMD $=-17.04 ; 95 \% \mathrm{CI},-63.79$ to $29.72 ; P=0.48$; Fig. 4). Heterogeneity was detected between studies $\left(I^{2}=75 \%\right.$; Fig. 4). Moreover, the results of subgroup analyses also showed that none of the subgroups revealed a significantly protective effect of AA on PTH levels with differences in the time of measurement (over 8 weeks: random effects model; $\mathrm{WMD}=4.95 ; 95 \% \mathrm{CI},-51.52$ to $61.41 ; P=0.86 ; I^{2}=0.0 \%$; over 3 to 6 months: random effects model; $\mathrm{WMD}=-26.42 ; 95 \% \mathrm{CI},-83.5$ to $30.67 ; P=0.36 ; I^{2}=81 \%$; Fig. 4a, Table 3 ) or the method of administration (IV administration: random effects model; WMD $=-0.16 ; 95 \% \mathrm{CI},-31.74$ to $31.42 ; P=0.99 ; I^{2}=0 \%$; Fig. $4 \mathrm{~b}$, Table 3 ), except for the study by Xie et al. (2010) in which AA was administered via dialysate. However, only one study of this type made it difficult to perform subgroup-analysis. 


\section{Kidney \\ Blood Pressure Research}

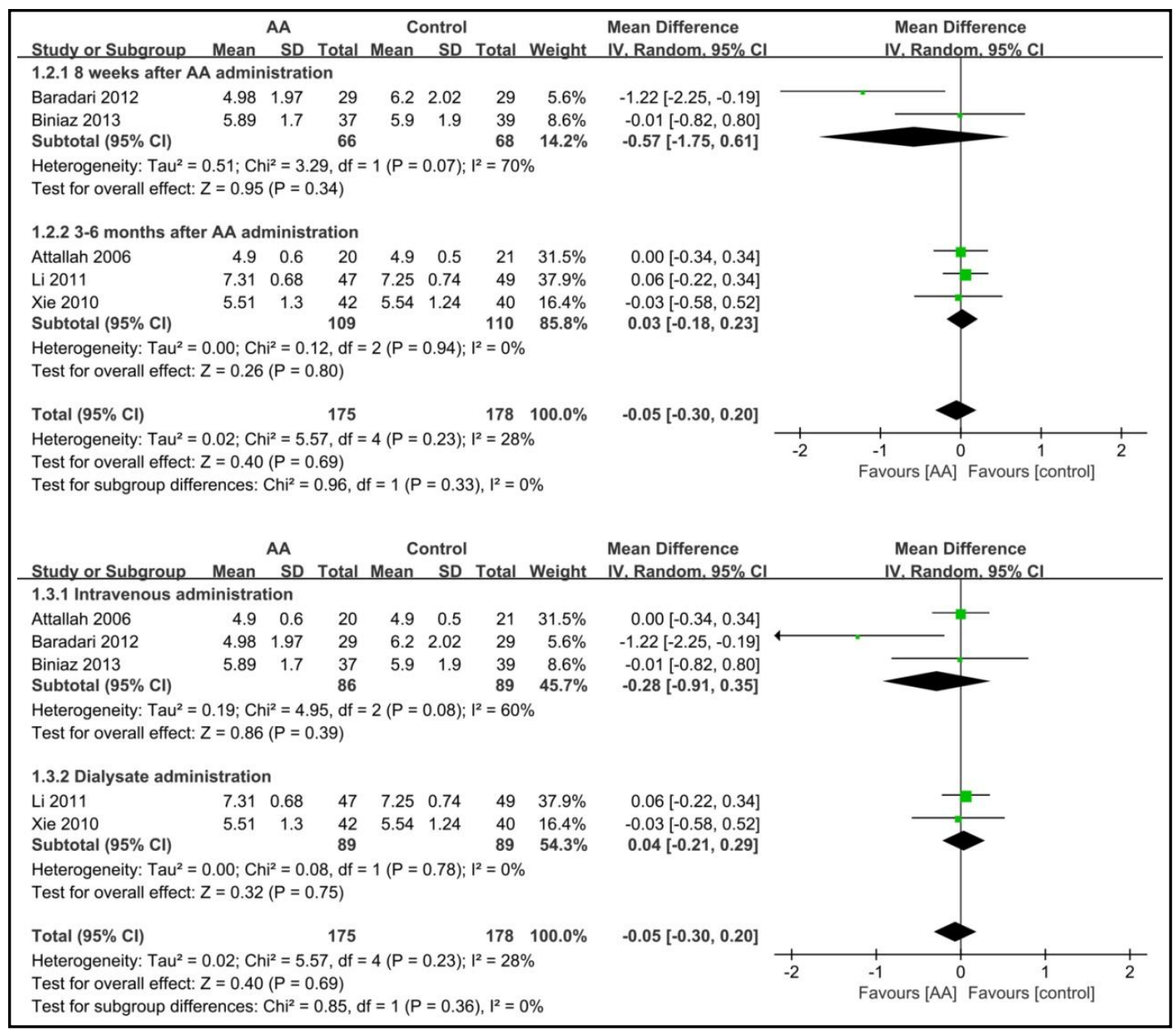

Fig. 2. Forest plots for $P$ outcomes. No significant difference in $P$ levels was seen between the AA therapy groups and the control groups. (a) and (b) None of the subgroups revealed any significant effect of AA on P with differences in the time of measurement or the method of administration. AA: ascorbic acid.

\section{Side effects and hospitalization}

No side effects were observed in our study. Two patients did not complete the study [29], one from the AA treatment group because of developing miliary tuberculosis and the other from the control group because a blood transfusion was required. Data regarding hospitalization were noted in one study [32] with 12 hospitalizations in the standard-care group and 11 hospitalizations in the $\mathrm{AA}$ treatment group.
Table 3. Subgroup analysis of the effect of AA treatment on P, Ca and PTH. Treatment effects were evaluated by weighted mean difference (WMD) and confidence intervals (CI). The $\mathrm{I}^{2}$ statistic was used to assess heterogeneity. Abbreviations: AA: ascorbic acid, PTH: parathyroid hormone, Ca: calcium, P: phosphate, NA: not applicable

\begin{tabular}{|c|c|c|c|c|c|}
\hline Subgroup & No. of Studies & WMD $(95 \%$ CI $)$ & P for Heterogeneity & $I^{2}$ & No. of Patients \\
\hline \multicolumn{6}{|c|}{ Measurement time after administration of AA (PTH) } \\
\hline 3-6 months & 3 & -83.5 to 30.67 & $<0.01$ & $81 \%$ & 141 \\
\hline 8 weeks & 2 & -51.52 to 61.41 & 0.87 & $0 \%$ & 134 \\
\hline \multicolumn{6}{|c|}{ Administrative method (PTH) } \\
\hline Dialysate & 1 & -66.64 to -57.2 & NA & NA & 82 \\
\hline Intravenous & 4 & -31.74 to 31.42 & 0.69 & $0 \%$ & 193 \\
\hline \multicolumn{6}{|c|}{ Measurement time after administration (Ca) } \\
\hline 3-6 months & 3 & -0.14 to 0.28 & 0.73 & $0 \%$ & 219 \\
\hline 8 weeks & 2 & 0.03 to 0.42 & 0.56 & $0 \%$ & 134 \\
\hline \multicolumn{6}{|c|}{ Administrative method (Ca) } \\
\hline Dialysate & 2 & -0.15 to 0.49 & 0.95 & $0 \%$ & 178 \\
\hline Intravenous & 3 & -0.01 to 0.31 & 0.36 & $2 \%$ & 175 \\
\hline \multicolumn{6}{|c|}{ Measurement time after administration (P) } \\
\hline 3-6 months & 3 & -0.18 to 0.23 & 0.94 & $0 \%$ & 219 \\
\hline 8 weeks & 2 & -1.75 to 0.61 & 0.07 & $70 \%$ & 134 \\
\hline \multicolumn{6}{|c|}{ Administrative method (P) } \\
\hline Dialysate & 2 & -0.21 to 0.29 & 0.78 & $0 \%$ & 178 \\
\hline Intravenous & 3 & -0.91 to 0.35 & 0.08 & $60 \%$ & 175 \\
\hline
\end{tabular}




\section{Kidney \\ Blood Pressure Research}

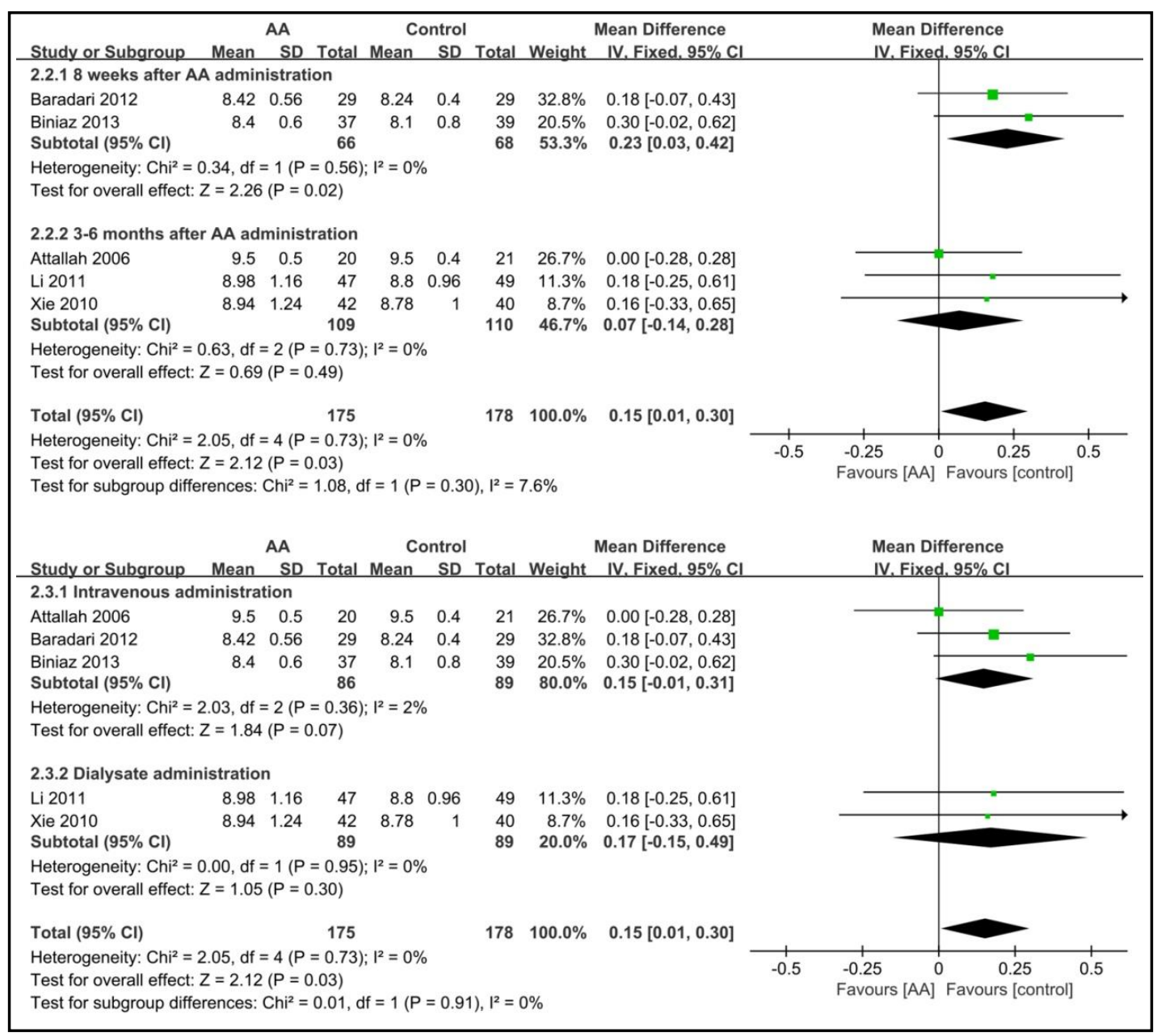

Fig. 3. Forest plots for Ca outcomes. The Ca increase from baseline was higher in the AA therapy groups versus placebo. (a) Over 8 weeks, AA therapy significantly elevated the levels of serum Ca, but the effects disappeared over 3-6 months. (b) The results of subgroup analysis indicated that different AA administration methods had no effect on serum Ca. AA: ascorbic acid.

\section{Publication bias}

We conducted Egger's linear regression test to assess publication bias, and the $P$ values for Egger's test were 0.16 for P data, 0.77 for Ca data and 0.02 for PTH data, which suggested a low likelihood of publication bias except for PTH. A bias assessment plot is shown as Fig. 5. 


\section{Kidney Blood Pressure Research}

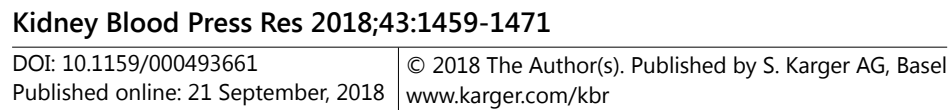

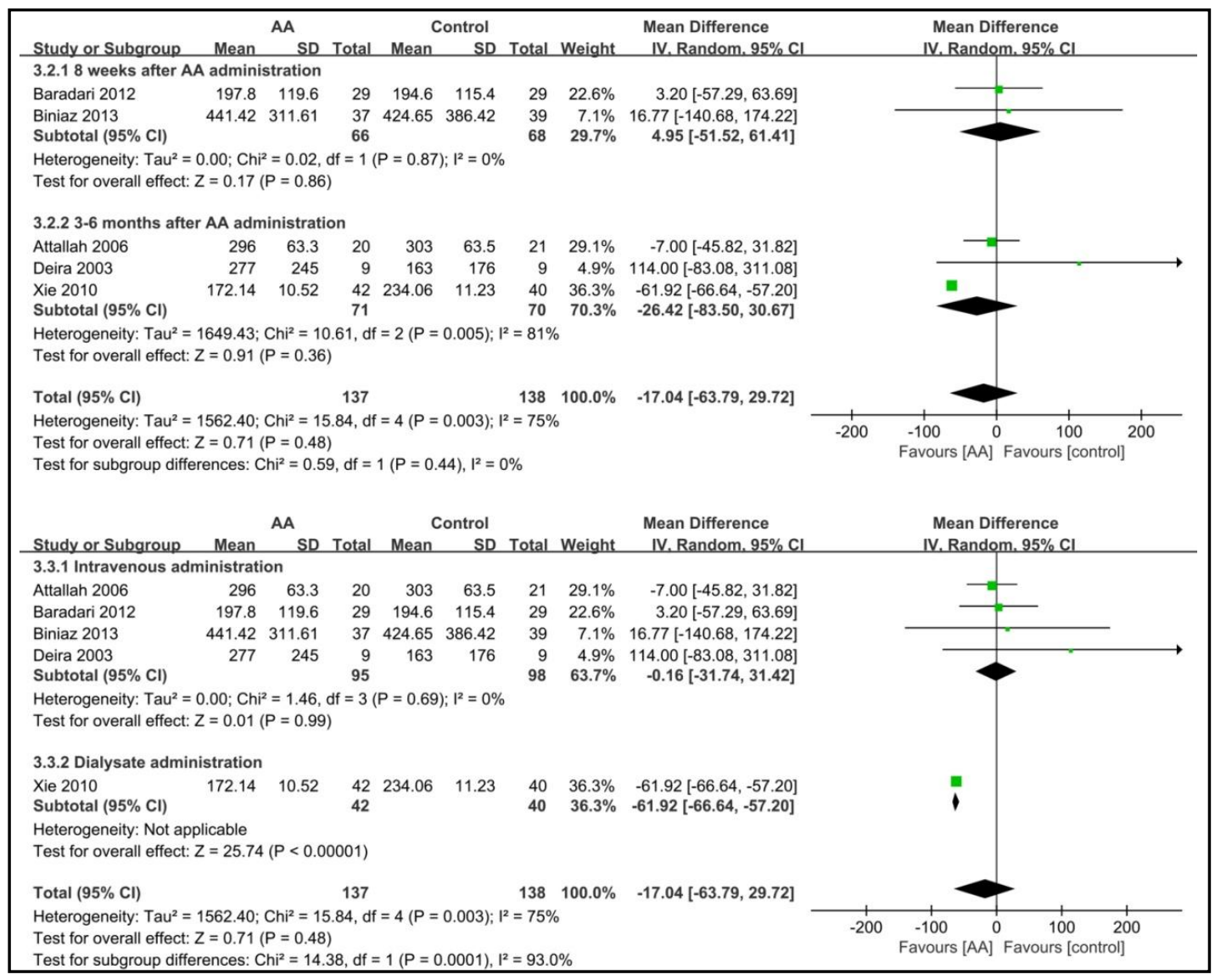

Fig. 4. Forest plots for PTH outcomes. No significant difference in PTH levels was seen between the AA therapy groups and the control groups. (a) and (b) None of the subgroups revealed any significant effect of AA on PTH with differences in the time of measurement or the method of administration, except for the study by Xie et al. (2010), because only one study made it difficult to perform subgroup-analysis. AA: ascorbic acid.

\section{Discussion}

Results of this systematic review and meta-analysis of six studies suggested that AA has no positive effect on CKD-MBD patients requiring HD. AA showed no significant effect on either serum P or PTH levels no matter whether the study was short-term or long-term. However, AA might raise serum Ca levels, but higher Ca levels are linked to higher mortality and increased risk of cardiovascular events [34-36].

Undoubtedly, there was some heterogeneity among the studies included. To avoid the influence of heterogeneity, this systematic review and meta-analysis analyzed the sources of heterogeneity, and found it mainly came from the length of follow-up and the method of administering the AA supplement.

The results of this systematic review and meta-analysis do not warrant the use of AA in HD patients who have developed CKD-MBD. Our meta-analysis included data from $371 \mathrm{HD}$ patients extracted from six studies. While the effects of AA on serum PTH levels varied from mild to moderate, the weight of the scientific evidence suggests that AA is irrelevant with respect to the PTH decline observed in HD patients. Meanwhile serum P levels also did not show any significant change with the administration of AA. In contrast, AA was associated with a slight but statistically significant increase of serum Ca concentration among the patients analyzed. In subgroup analysis, we noted that intravenous administration of AA had no effect on serum PTH or P concentration while dialysate administration of AA obviously 


\section{Kidney \\ Blood Pressure Research}

decreased PTH in the study by Li et al. [33]. Subgroup analysis also demonstrated that AA did not cause a significant change in serum PTH or P no matter whether the data were collected at 8 weeks or 3-6 months after AA treatment. Likewise, intravenous or dialysate administration of AA did not change the serum Ca levels over 3-6 months, but could increase serum Ca levels in the short term.

The mechanism via which AA raises serum $\mathrm{Ca}$ levels in the short term may rely on the fact that $\mathrm{AA}$ promotes the absorption of vitamin $\mathrm{D}$ and Ca from food. However, this effect on $\mathrm{Ca}$ levels will disappear over 3-6 months and thus, the prescription of AA cannot affect $\mathrm{Ca}$ concentrations in the long term.

Hypercalcemia is often reported among serious CKD patients and is linked to elevated cardiovascular disease and increased mortality, especially in endstage renal disease (ESRD) patients since the 2009 KDIGO CKD-MBD guideline $[11,12,34-36]$. Data from the Dialysis Outcomes and Practice Patterns Study (DOPPS) among patients on hemodialysis for over 6 months suggested a higher risk of cardiovascular and all-cause mortality in patients with Ca concentrations over $10 \mathrm{mg} / \mathrm{dL}, \mathrm{P}$ levels over $7 \mathrm{mg} / \mathrm{dL}$, and PTH concentrations over $600 \mathrm{pg} / \mathrm{mL}[4,34]$. Two studies implicated hypercalcemia in higher risk of death, all-cause mortality, CVD mortality and CVD events in HD patients [5, 37]. Another study by DaVita Dialysis Clinics concluded that hypercalcemia was an indicator of increased death risk [7]. Consequently, AA increasing Ca levels may be a risk factor in CKD-MBD patients as it will increase the risk of cardiovascular events and death.

Ott et al. reported a case in which a bone biopsy was performed on a patient who had been receiving hemodialysis for 23 years which suggested that high doses of vitamin $\mathrm{C}$ might be associated with bone oxalate deposition [38]. Once AA is absorbed in the human body, it will be metabolized to oxalate, which provides conditions for the development of hyperoxalemia and oxalate deposition. Zazgornik et al. proposed that CKD patients with HD should avoid high doses of AA due to the risk of hyperoxalemia [39]. Intravenous AA

Fig. 5. Bias assessment plot for the effect of AA on P, Ca and PTH by Egger's test. AA: ascorbic acid. 


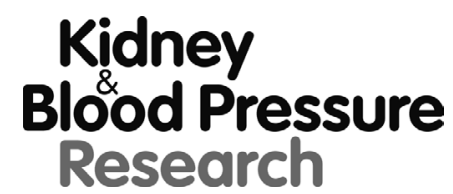

\begin{tabular}{l}
\hline Kidney Blood Press Res 2018;43:1459-1471 \\
\hline \begin{tabular}{l|l} 
DOI: 10.1159/000493661 & (c) 2018 The Author(s). Published by S. Karger AG, Basel \\
Published online: 21 September, 2018 & www.karger.com/kbr
\end{tabular}
\end{tabular}

Ke et al:: Ascorbic Acid on Mineral and Bone Disorders in Hemodialysis Patients

supplementation may be one of the factors causing hyperoxaluria and oxalate nephropathy which may cause deterioration of kidney function and ultimately, renal failure [40]. Thus, potential complications must be taken into consideration when prescribing AA for CKD patients.

Higher acid load and acidosis is linked to increased serum phosphorus levels and elevated phosphaturia, which are not in accordance with Fibroblast growth factor 23 (FGF23) or serum PTH levels, which may be a compensatory mechanism to maintain acidbase homeostasis in CKD patients by excreting the titratable acid [41]. AA, also known as vitamin $C$, is a slightly weak organic acid and this means that the intake of AA may raise the serum P levels and lead to the phenomenon of phosphaturia, which may progressively worsen homeostasis disturbances.

Data from 185, 277 HD patients in Japan showed that higher serum alkaline phosphatase (ALP) levels were associated with mortality [42]. It was likewise advised that ALP levels were more consistent with mortality than PTH, Ca and P concentrations [43, 44]. Moreover, bone-specific alkaline phosphatase (bALP) is still considered valuable as a marker of bone turnover [18] because bALP contributes to the diagnosis, fracture risk prediction and fracture prognosis of CKD-MBD patients. Sardiwal et al. also recommended utilizing bALP as a substitute or supplementary method to reflect the condition of CKD patients and predict their prognosis [45]. FGF23 is another important biomarker for CKD-MBD[18, 46], it not only changes our understanding of CKD-MBD, but also reveals the complex series of interactions and endocrine negative feedback loop between kidney, parathyroid, small intestine and bone. FGF23 is also strongly associated with mortality in patients with CKD[47]. In summary, ALP, bALP and FGF23 should be included as important parameters to more precisely reflect the outcomes in CKD-MBD patients.

There are several limitations to this systematic review and meta-analysis. The shortterm follow-up and small number of patients restricted our meta-analysis. The PTH assays used in the original studies were not able to distinguish bioactive non-oxidized PTH from oxidized PTH which is not a ligand of the PTH receptor. The likelihood of publication bias regarding $\mathrm{P}$ and $\mathrm{Ca}$ is low, while there is the possibility of publication bias regarding $\mathrm{PTH}$, but the small number of included studies $(<10)$ limits our power to properly assess publication bias. Consequently further studies are needed to verify our conclusions. In addition, different experiments had different designs and the condition of patients also differed, which is another limitation. Thus, further research with a large number of patients and long-term follow-up as well as appropriate controls is needed in the future. Moreover, in order to obtain more accurate parameters and better observation, it will be better to dynamically detect the parameters as they are affected by various factors such as diets, drugs, circadian rhythm and the intake of Vitamin D. Finally, as in many meta-analyses, we were limited by the data manifested in the original studies.

\section{Conclusion}

Our systematic review and meta-analysis did not support the prescription of AA to HD patients with CKD-MBD. AA had no positive effect on CKD-MBD patients as it could not influence the serum P or PTH levels but did raise serum Ca levels in the short-term.

\section{Acknowledgements}

This work was supported by Affiliated Hospital of Chengdu University (No. 201401), Guangdong Provincial Science and Technology Foundation (No. 2014A030313544), the National Natural Science Foundation (No. 81670656 and 81870508), Special Fund for NHFPC Scientific Research in the Public Welfare (No. 201502023), Guangzhou City Science 


\section{Kidney \\ Blood Pressure Research}

Ke et al.: Ascorbic Acid on Mineral and Bone Disorders in Hemodialysis Patients

and Technology Project (No. 201707010009), National Key Technology R\&D Program (No. 2011BAI10B06), National key clinical specialist construction Programs of China, and Medical Scientific Research Foundation of Guangdong Province General Hospital.

\section{Disclosure Statement}

The authors declare they have no conflicts of interest.

\section{References}

$\longrightarrow 1$ Stevens PE, Levin A: Evaluation and management of chronic kidney disease: synopsis of the kidney disease: improving global outcomes 2012 clinical practice guideline. Ann Intern Med 2013;158:825-830.

-2 Saran R, Li Y, Robinson B, Abbott KC, Agodoa LY, Ayanian J, Bragg-Gresham J, Balkrishnan R, Chen JL, Cope E, Eggers PW, Gillen D, Gipson D, Hailpern SM, Hall YN, He K, Herman W, Heung M, Hirth RA, Hutton D, et al.: US Renal Data System 2015 Annual Data Report: Epidemiology of Kidney Disease in the United States. Am J Kidney Dis 2016;67:Svii, S1-305.

-3 GBD 2013 Mortality and Causes of Death Collaborators: Global, regional, and national age-sex specific allcause and cause-specific mortality for 240 causes of death, 1990-2013: a systematic analysis for the Global Burden of Disease Study 2013. Lancet 2015;385:117-171.

4 Tentori F, Blayney MJ, Albert JM, Gillespie BW, Kerr PG, Bommer J, Young EW, Akizawa T, Akiba T, Pisoni RL, Robinson BM, Port FK: Mortality risk for dialysis patients with different levels of serum calcium, phosphorus, and PTH: the Dialysis Outcomes and Practice Patterns Study (DOPPS). Am J Kidney Dis 2008;52:519-530.

5 Block GA, Klassen PS, Lazarus JM, Ofsthun N, Lowrie EG, Chertow GM: Mineral metabolism, mortality, and morbidity in maintenance hemodialysis. J Am Soc Nephrol 2004;15:2208-2218.

-6 Taniguchi M, Fukagawa M, Fujii N, Hamano T, Shoji T, Yokoyama K, Nakai S, Shigematsu T, Iseki K, Tsubakihara Y: Serum phosphate and calcium should be primarily and consistently controlled in prevalent hemodialysis patients. Ther Apher Dial 2013;17:221-228.

-7 Kalantar-Zadeh K, Kuwae N, Regidor DL, Kovesdy CP, Kilpatrick RD, Shinaberger CS, McAllister CJ, Budoff MJ, Salusky IB, Kopple JD: Survival predictability of time-varying indicators of bone disease in maintenance hemodialysis patients. Kidney Int 2006;70:771-780.

-8 Floege J, Kim J, Ireland E, Chazot C, Drueke T, de Francisco A, Kronenberg F, Marcelli D, Passlick-Deetjen J, Schernthaner G, Fouqueray B, Wheeler DC: Serum iPTH, calcium and phosphate, and the risk of mortality in a European haemodialysis population. Nephrol Dial Transplant 2011;26:1948-1955.

-9 Nolan CR: Strategies for improving long-term survival in patients with ESRD. J Am Soc Nephrol 2005;16:S120-127.

10 McCarley PB, Arjomand M: Mineral and bone disorders in patients on dialysis: physiology and clinical consequences. Nephrol Nurs J 2008;35:59-64.

11 Rivara MB, Ravel V, Kalantar-Zadeh K, Streja E, Lau WL, Nissenson AR, Kestenbaum B, de Boer IH, Himmelfarb J, Mehrotra R: Uncorrected and Albumin-Corrected Calcium, Phosphorus, and Mortality in Patients Undergoing Maintenance Dialysis. J Am Soc Nephrol 2015;26:1671-1681.

-12 Streja E, Wang HY, Lau WL, Molnar MZ, Kovesdy CP, Kalantar-Zadeh K, Park J: Mortality of combined serum phosphorus and parathyroid hormone concentrations and their changes over time in hemodialysis patients. Bone 2014;61:201-207.

$>13$ de Jager DJ, Vervloet MG, Dekker FW: Noncardiovascular mortality in CKD: an epidemiological perspective. Nat Rev Nephrol 2014;10:208-214.

-14 Cozzolino M, Galassi A, Conte F, Mangano M, Di Lullo L, Bellasi A: Treatment of secondary hyperparathyroidism: the clinical utility of etelcalcetide. Ther Clin Risk Manag 2017;13:679-689.

15 Brandenburg VM, Cozzolino M, Ketteler M: Calciphylaxis: a still unmet challenge. J Nephrol 2011;24:142148. 


\section{Kidney \\ Bloód Pressure Research}

16 Nigwekar SU, Kroshinsky D, Nazarian RM, Goverman J, Malhotra R, Jackson VA, Kamdar MM, Steele DJ, Thadhani RI: Calciphylaxis: risk factors, diagnosis, and treatment. Am J Kidney Dis 2015;66:133-146.

17 Yoshikawa M, Takase 0, Tsujimura T, Sano E, Hayashi M, Takato T, Hishikawa K: Long-term effects of low calcium dialysates on the serum calcium levels during maintenance hemodialys is treatments: A systematic review and meta-analysis. Sci Rep 2018;8:5310.

18 Isakova T, Nickolas TL, Denburg M, Yarlagadda S, Weiner DE, Gutierrez OM, Bansal V, Rosas SE, Nigwekar S, Yee J, Kramer H: KDOQI US Commentary on the 2017 KDIGO Clinical Practice Guideline Update for the Diagnosis, Evaluation, Prevention, and Treatment of Chronic Kidney Disease-Mineral and Bone Disorder (CKD-MBD). Am J Kidney Dis 2017;70:737-751.

19 Martin KJ, Gonzalez EA: Prevention and control of phosphate retention/hyperphosphatemia in CKD-MBD: what is normal, when to start, and how to treat? Clin J Am Soc Nephrol 2011;6:440-446.

20 Chertow GM, Block GA, Correa-Rotter R, Drueke TB, Floege J, Goodman WG, Herzog CA, Kubo Y, London GM, Mahaffey KW, Mix TC, Moe SM, Trotman ML, Wheeler DC, Parfrey PS: Effect of cinacalcet on cardiovascular disease in patients undergoing dialysis. N Engl J Med 2012;367:2482-2494.

21 Deicher R, Ziai F, Bieglmayer C, Schillinger M, Horl WH: Low total vitamin C plasma level is a risk factor for cardiovascular morbidity and mortality in hemodialysis patients. J Am Soc Nephrol 2005;16:1811-1818.

22 Friedman PA, Coutermarsh BA, Kennedy SM, Gesek FA: Parathyroid hormone stimulation of calcium transport is mediated by dual signaling mechanisms involving protein kinase A and protein kinase C. Endocrinology 1996;137:13-20.

23 Pearce SH, Thakker RV: The calcium-sensing receptor: insights into extracellular calcium homeostasis in health and disease. J Endocrinol 1997;154:371-378.

24 Sergeev IN, Arkhapchev YP, Spirichev VB: Ascorbic acid effects on vitamin D hormone metabolism and binding in guinea pigs. J Nutr 1990;120:1185-1190.

25 Calo LA, Savica V, Piccoli A, Fusaro M, D’Angelo A, Davis PA: Reduction of hyperphosphatemia is related with the reduction of C-reactive protein in dialysis patients. Study in sevelamer-resistant dialysis patients treated with chitosan chewing gum as salivary phosphate binder. Ren Fail 2011;33:11-14.

-26 Richter A, Kuhlmann MK, Seibert E, Kotanko P, Levin NW, Handelman GJ: Vitamin C deficiency and secondary hyperparathyroidism in chronic haemodialysis patients. Nephrol Dial Transplant 2008;23:20582063.

27 Xie HC, Zhao XG, Wang XF: The effect of dialysate containing vitamin C on secondary hyperparathyroidism. Chinese Journal of Blood Purification 2010;9:258-260.

28 Gholipour Baradari A, Emami Zeydi A, Espahbodi F, Aarabi M: The effect of intravenous vitamin C on the phosphorus level reduction in hemodialysis patients: a double blind randomized clinical trial. Med Glas (Zenica) 2012;9:37-41.

29 Deira J, Diego J, Martinez R, Oyarbide A, Gonzalez A, Diaz H, Grande J: Comparative study of intravenous ascorbic acid versus low-dose desferroxamine in patients on hemodialysis with hyperferritinemia. J Nephrol 2003;16:703-709.

-30 Biniaz V, Nemati E, Tayebi A, Sadeghi Shermeh M, Ebadi A: The effect of vitamin C on parathyroid hormone in patients on hemodialysis with secondary hyperparathyroidism: a double blind, placebo-controlled study. Nephrourol Mon 2013;5:962-966.

31 Ke G: The effect of ascorbic acid on chronic kidney disease-mineral and bone disorder in hemodialysis patients: a systematic review and meta-analysis. URL: http://www.crd.york.ac.uk/PROSPERO/display_ record.php?ID=CRD42018093372.

-32 Attallah N, Osman-Malik Y, Frinak S, Besarab A: Effect of intravenous ascorbic acid in hemodialysis patients with EPO-hyporesponsive anemia and hyperferritinemia. Am J Kidney Dis 2006;47:644-654.

33 Li GH, Zhao XG, Zhang HT, Wang K, Zhang BH: The Effect of Dialysate Containing Vitamin C Intervention on Arterial Calcification of Patients of Maintenance Hemodialysis. Chinese General Practice 2011;14:19111913.

34 Fukagawa M, Kido R, Komaba H, Onishi Y, Yamaguchi T, Hasegawa T, Kurita N, Fukuma S, Akizawa T, Fukuhara S: Abnormal mineral metabolism and mortality in hemodialysis patients with secondary hyperparathyroidism: evidence from marginal structural models used to adjust for time-dependent confounding. Am J Kidney Dis 2014;63:979-987. 


\section{Kidney \\ Blood Pressure Research}

\begin{tabular}{l}
\hline Kidney Blood Press Res 2018;43:1459-1471 \\
\hline \begin{tabular}{l|l} 
DOI: 10.1159/000493661 & ( ) 2018 The Author(s). Published by S. Karger AG, Basel \\
Published online: 21 September, 2018 & wwarger.com/kbr
\end{tabular} \\
\hline
\end{tabular}

Ke et al.: Ascorbic Acid on Mineral and Bone Disorders in Hemodialysis Patients

-35 Lacson E, Jr., Wang W, Hakim RM, Teng M, Lazarus JM: Associates of mortality and hospitalization in hemodialysis: potentially actionable laboratory variables and vascular access. Am J Kidney Dis 2009;53:7990.

-36 Fein PA, Asadi S, Singh P, Hartman W, Stuto S, Chattopadhyay J, Avram MM: Relationship between alkaline phosphatase and all-cause mortality in peritoneal dialysis patients. Adv Perit Dial 2013;29:61-63.

-37 Moldovan D, Rusu C, Kacso IM, Potra A, Patiu IM, Gherman-Caprioara M: Mineral and bone disorders, morbidity and mortality in end-stage renal failure patients on chronic dialysis. Clujul Med 2016;89:94-103.

-38 Ott SM, Andress DL, Sherrard DJ: Bone oxalate in a long-term hemodialysis patient who ingested high doses of vitamin C. Am J Kidney Dis 1986;8:450-454.

39 Zazgornik J, Balcke P, Rokitansky A, Schmidt P, Kopsa H, Minar E, Graninger W: Excessive myocardial calcinosis in a chronic hemodialyzed patient. Klin Wochenschr 1987;65:97-100.

40 Marques S, Santos S, Fremin K, Fogo AB: A Case of Oxalate Nephropathy: When a Single Cause Is Not Crystal Clear. Am J Kidney Dis 2017;70:722-724.

-41 Khairallah P, Isakova T, Asplin J, Hamm L, Dobre M, Rahman M, Sharma K, Leonard M, Miller E 3rd, Jaar B, Brecklin C, Yang W, Wang X, Feldman H, Wolf M, Scialla JJ: Acid Load and Phosphorus Homeostasis in CKD. Am J Kidney Dis 2017;70:541-550.

42 Maruyama Y, Taniguchi M, Kazama JJ, Yokoyama K, Hosoya T, Yokoo T, Shigematsu T, Iseki K, Tsubakihara Y: A higher serum alkaline phosphatase is associated with the incidence of hip fracture and mortality among patients receiving hemodialysis in Japan. Nephrol Dial Transplant 2014;29:1532-1538.

43 Liu CT, Lin YC, Lin YC, Kao CC, Chen HH, Hsu CC, Wu MS: Roles of Serum Calcium, Phosphorus, PTH and ALP on Mortality in Peritoneal Dialysis Patients: A Nationwide, Population-based Longitudinal Study Using TWRDS 2005-2012. Sci Rep 2017;7:33.

44 Rhee CM, Molnar MZ, Lau WL, Ravel V, Kovesdy CP, Mehrotra R, Kalantar-Zadeh K: Comparative mortalitypredictability using alkaline phosphatase and parathyroid hormone in patients on peritoneal dialysis and hemodialysis. Perit Dial Int 2014;34:732-748.

-45 Sardiwal S, Magnusson P, Goldsmith DJ, Lamb EJ: Bone alkaline phosphatase in CKD-mineral bone disorder. Am J Kidney Dis 2013;62:810-822.

46 Naveh-Many T, Silver J: The Pas de Trois of Vitamin D, FGF23, and PTH. J Am Soc Nephrol 2017;28:393-395.

-47 Isakova T, Cai X, Lee J, Xie D, Wang X, Mehta R, Allen NB, Scialla JJ, Pencina MJ, Anderson AH, Talierco J, Chen J, Fischer MJ, Steigerwalt SP, Leonard MB, Hsu CY, de Boer IH, Kusek JW, Feldman HI, Wolf M, et al.: Longitudinal FGF23 Trajectories and Mortality in Patients with CKD. J Am Soc Nephrol 2018;29:579-590. 